\section{Basic and Applied Ecology}

www.elsevier.com/locate/baae

\title{
Effects of inter-annual landscape change on interactions between cereal aphids and their natural enemies
}

\author{
Zi-Hua Zhao ${ }^{\text {, }}$, Cang Hui ${ }^{b}$, Fang Ouyang ${ }^{a}$, Jun-He Liu ${ }^{c}$, Xiao-Qing Guan ${ }^{\text {d }}$, \\ Da-Han $\mathrm{He}^{\mathrm{d}}$, Feng Ge $\mathrm{Ge}^{\mathrm{a}, *}$

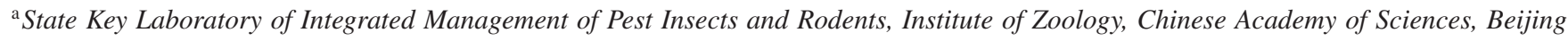 \\ 100101, China \\ ${ }^{\mathrm{b}}$ Centre for Invasion Biology, Department of Botany and Zoology, Stellenbosch University, Matieland 7602, South Africa \\ ${ }^{\mathrm{c}}$ Department of Biological Engineering, Huanghuai University, Zhumadian 463000, China \\ ${ }^{\mathrm{d}}$ Agricultural School, Ningxia University, Yinchuan 750021, China
}

Received 22 September 2012; accepted 13 June 2013

Available online 12 July 2013

\begin{abstract}
The agricultural intensification and the subsequent habitat changes in agroecosystem can strongly affect biological control services. We here examine the influence of inter-annual landscape change in wheat field area on interactions of cereal aphids and their natural enemies, as well as the efficacy of biological control using data collected from a 4-year experiment in Northwest China. Two hypotheses were tested. (i) Population densities decline following an inter-annual expansion of wheat crop proportion cover due to dilution and crowding effects. (ii) Species that are specialists or at higher trophic levels are more sensitive to bottomup disturbance by inter-annual change in percent cover of wheat crop. Results showed the population densities of one cereal aphid (Macrosiphum avenae), one parasitic wasp (Aphidius avenae), two specialist predators (ladybirds: Hippodamia variegata and $H$. tredecimpunctata) and one hyperparasitic wasp (Pachyneuron aphidis) declined following the expansion of wheat crop areas, supporting the predictions of inter-annual dilution and crowding effects. In contrast, the populations of one cereal aphid (Schizaphis graminum), one parasitic wasp (A. gifuensis), two generalist predators (spiders: Pardosa astrigera; carabid beetles: Chlaenius pallipes), and two hyperparasitic wasps (Asaphes suspensus, and Alloxysta sp.) did not respond to inter-annual landscape change. The two hypotheses were partially supported but with noticeable exceptions, and the bio-control efficiency declined with the increase of the proportion cover of wheat field in agricultural landscape. Overall, different responses of cereal aphids and their natural enemies make it difficult but still possible to optimize inter-annual landscape change for enhancing the parasitism rate and predator-prey ratio.
\end{abstract}

\section{Zusammenfassung}

Die Intensivierung der Landwirtschaft und die daraus folgenden Änderungen der Habitate in Agrarökosystemen können die biologische Schädlingsbekämpfung stark beeinflussen. Wir untersuchen hier den Einfluss der jährlichen Änderungen des Flächenanteils von Weizenfeldern in der Landschaft auf die Interaktionen zwischen Getreideblattläusen und ihren natürlichen Feinden sowie auf die Effektivität der biologischen Schädlingsbekämpfung. Wir nutzten Daten aus einem vierjährigen Experiment im Nordwesten Chinas. Zwei Hypothesen wurden getestet: (1) Nach einer Ausweitung des Flächenanteils der Weizenfelder gehen die Populationsdichten zurück als Folge von Verdünnungs- und Konzentrationseffekten. (2) Spezialisten und

\footnotetext{
*Corresponding author. Tel.: +86 01064807130 ; fax: +86 01064807130

E-mail address: gef@ioz.ac.cn (F. Ge).
} 
Arten höherer Trophiestufen sind empfindlicher gegen die bottom-up-Störung durch die von Jahr zu Jahr wechselnden Flächenanteile der Weizenfelder.

Die Ergebnisse zeigten, dass die Populationsdichten einer Getreideblattlaus (Macrosiphum avenae), einer parasitoiden Wespe (Aphidius avenae), zweier spezialisierter Räuber (Marienkäfer: Hippodamia variegata und H. tredecimpunctata) und einer hyperparasitischen Wespe (Pachyneuron aphidis) in Folge der Zunahme der Weizenfelder abnahmen, was die Vorhersage von Verdünnungs- und Konzentrationseffekten unterstützt. Dagegen reagierten die Populationen einer Getreideblattlaus (Schizaphis graminum), eines Parasitoiden (A. gifuensis), zweier generalistischer Räuber (Spinnen: Pardosa astrigera; Laufkäfer: Chlaenius pallipes), und zweier Hyperparasitoide (Asaphes suspensus und Alloxysta sp.) nicht auf die alljährlichen Änderungen der Landschaft.

Die beiden Hypothesen wurden zum Teil bestätigt, aber mit auffälligen Ausnahmen, und die Effektivität der biologischen Kontrolle sank mit der Zunahme des Flächenanteils der Weizenfelder. Insgesamt machen es die unterschiedlichen Reaktionen der Getreideblattläuse und ihrer natürlichen Gegenspieler schwierig aber nicht unmöglich, die jährlichen Änderungen der Landschaft so zu optimieren, dass Parasitierungsraten und das Räuber-Beute-Verhältnis gesteigert werden.

(C) 2013 Gesellschaft für Ökologie. Published by Elsevier GmbH. All rights reserved.

Keywords: Crop rotation; Crowding effect; Dilution effect; Parasitism; Predator-prey ratio

\section{Introduction}

Landscape-scale agricultural activities can profoundly disturb interspecific relationships and degrade the function and service of many bio-control agents (Thies, Steffan-Dewenter, \& Tscharntke 2008; Zaller, Moser, Drapela, \& Frank 2009). This is because agricultural landscape change can rapidly relocate resources and affect food distribution and habitat quality for insects. To this end, agricultural landscape change can play particularly important roles in the efficiency and success of pest control (Haenke, Scheid, Scharfer, Tscharntke, \& Thies 2009; Tscharntke et al. 2012).

Two effects of landscape change on insect densities have been proposed in the literature (see Appendix A: Fig. A1; Tscharntke et al. 2012). The crowding effect (Grez, Zaviezo, Tischendorf, \& Fahrig 2004) predicts that the population density of insects should increase in the remaining habitat patch for a short period once a part of the patch has been removed. In contrast, the dilution effect suggests that the increase of patch size will result in the declines of insect population densities in the newly ameliorated habitat (Grez et al. 2004). Indeed, as Otway, Hector, and Lawton (2005) put it, both the crowding and dilution effects on insect populations are important mechanisms to be considered for improving crop yield.

In Northwest China spring wheat is an important economic crop which has experienced severe outbreaks of cereal aphids since the 1980s. Due to the high number of pests and plant diseases, spring wheat is cultivated at an interval of 1-2 years. The rotation of cultivated wheat has driven rapid compositional changes in the agricultural landscape and results in a mosaic pattern of crop fields (Bianchi, Booij, \& Tscharntke 2006), not only affecting the dynamics of cereal aphids and their natural enemies but also the structure and function of regional insect food webs (Gagic et al. 2011).
Two cereal aphid pests are dominant in the region: Macrosiphum avenae and Schizaphis graminum, sharing the same natural enemies (including parasitoids and predators). Specialized Aphidius parasitic wasps are used as bio-control agents to suppress the cereal aphids. However, the existence of a large number of hyperparasitic wasps has discredited the bio-control efficiency of these parasitic wasps. Moreover, both polyphagous generalist predators (e.g. spiders and carabid beetles) and oligophagous specialist predators (Hippodamia ladybirds) can also suppress cereal aphid populations by attacking immature and adult aphids (Brewer \& Elliott 2004). These predator-prey interactions combined with host-parasitoid interactions will further complicate our understanding of the biological control of cereal aphids (Schmidt, Thies, Nentwig, \& Tscharntke 2008; Thies et al. 2011).

A quantitative assessment of the effects of crop patch structure changes on the biotic interactions in the agricultural landscape and the efficacy of the biological control is still lacking and urgently needed (Wäckers, van Rijn, \& Heimpel 2008). Here, we report the results from a 4-year experiment that examines the effect of inter-annual change in percent cover of wheat fields on interactions between cereal aphids and their natural enemies. Two hypotheses were specifically tested. First, in a mosaic landscape with rotating wheat crops, the local densities of insects within field patches are expected to decline when the wheat area increases inter-annually (i.e. the dilution effect) and to increase when the wheat area is reduced inter-annually (i.e. the crowding effect) (Grez et al. 2004). Second, species at higher trophic levels or specialists could be more susceptible and sensitive to bottom-up disturbance, whilst species at lower trophic levels or generalists could be more robust against these landscape disturbances. Our research thus highlights the complexity of the bottom-up effect of landscape disturbances on food-web sensitivity and bio-control efficacy. 


\section{Material and methods}

\section{Landscape data}

The experiment was conducted in 23 agricultural landscapes (sites) of Xingqing District, Ningxia Hui Autonomous Region in Northwest China (see Appendix A: Fig. A2), where spring wheat Triticum aestivum is the dominant crop (29\%) according to the total cropping area, followed by corn Zea mays $(22 \%)$, rice Oryza sativa $(11 \%)$, soybean Glycine max $(8 \%)$, potato Solanum tuberosum $(7 \%)$, Chinese wolfberry Lycium chinense (6\%) and sorghum Sorghum bicolor (3\%). The experiment included both heterogeneous and homogeneous landscapes. A gradient of these landscapes was studied, from simple landscapes with intensive land use (89.3\% arable lands) to complex landscapes with a high percentage of noncrop habitats $(39.6 \%$ arable lands). Each of the 23 sites was designed to undergo either an inter-annual expansion or reduction of their wheat crop area during 2008-2011 (see Appendix A: Fig. A2).

Data on the spatial distributions of wheat crops were derived from the Cropland Data Layer, with a 30-m resolution, and remotely sensed land cover maps available from the Ningxia Research Academy of Environmental Sciences. Only wheat fields were considered as they are the most important habitat for cereal aphids from April to July. Proportion of wheat fields was calculated as the area of wheat crop divided by the total area of a site. In each site, wheat crop changes within $500 \mathrm{~m}$ radius to the site center were used to calculate the inter-annual landscape change. This radius has been adopted in many other studies as an appropriate scale for conducting landscape analysis of natural enemy-pest interactions in agro-ecosystems (Schmidt et al. 2008). Specifically, the inter-annual change in relative wheat crop cover was calculated as follows,

$\Delta \%=\frac{\operatorname{AREA}_{t+1}-\mathrm{AREA}_{t}}{\mathrm{AREA}_{t}} \times 100$

where $\mathrm{AREA}_{t+1}$ and $\mathrm{AREA}_{t}$ are the area sizes of wheat field in two consecutive years (Thies et al. 2008). The nearest neighbor distances of these sites were ranging from 1000 to $1800 \mathrm{~m}$ (see Appendix A: Fig. A2).

The semi-natural habitats in these sites (e.g. forage [alfalfa] areas, grassy margins and walking paths) remained unchanged and were not correlated to the inter-annual change in wheat crop proportion cover $(r=-0.17 ; P=0.394, n=23)$. The direction of inter-annual landscape change in relative wheat crop cover (either expanding or contracting) can be different from year to year for each site. All landscape metrics were computed using the Patch Analyst extension of FRAGSTATS (ArcGIS 9.3 2008).

To minimize the problem of associated changes, we planted the same spring wheat variety of Ning-spring 43 under the same abiotic conditions. The soil type in the region is chernozem. Compound fertilizer for wheat $(\mathrm{N}: \mathrm{P}: \mathrm{K}=16: 16: 8)$ was applied to all wheat fields in early
April (300 kg/ha). Wheat fields were irrigated by water from the Yellow River during early April, May, and mid June, respectively, and were harvested in mid July using a wheat combine harvester. Other agricultural practices were kept nearly the same across the wheat fields of different sites. The wheat density was $400-450$ plants $\mathrm{m}^{-2}$ with an extra $5 \%$ initially sown to compensate for loss from agricultural practices (e.g. weed harrowing). Changes of wheat crop areas in each site were designed below $\pm 15 \%$ in two consecutive years. Insecticides and herbicides were not used from March to June in the studied wheat fields.

\section{Insect sampling}

Cereal aphids and their natural enemies were sampled three times per year during the peak of cereal aphid populations from 5 to 25 May in 2009-2011 by both visual observation and hand collection. In each site, five randomly selected spots were used for insect sampling in the wheat fields (Zhao, He, \& Hui 2012). Each chosen spot was also kept more than $20 \mathrm{~m}$ away from wheat field margins to avoid edge effects. One hundred tillers were randomly selected at each spot, and 500 tillers were thus screened per site. Density of cereal aphid was calculated as individuals per 100 tillers (ipt hereafter).

Both live and mummy aphids were collected and taken to a lab for rearing. Aphids that died during the rearing were dissected to decide whether they were parasitized. All mummies were stored individually in gelatin capsules until emergence of adult parasitoids. The gelatin capsules were kept in test tubes sealed with a damp cotton plug and placed in a climate chamber at $20^{\circ} \mathrm{C}$ with $14 \mathrm{~h}$ light and $10 \mathrm{~h}$ darkness. The gelatin capsules with mummies were examined twice daily for the first month for the emergence of adults, and once every 2 days in the following month. Mummies, from which a parasitoid had not emerged for 2 months, were dissected to examine the cause and were classified as either aestivating or dead (Zhao et al. 2012). All parasitoids and hyperparasitoids were identified to species (see Appendix A: Table A1). Parasitism $\left(N_{\text {parasitoid }} /\left(N_{\text {aphids }}+N_{\text {parasitoid }}\right)\right)$; i.e. the proportion of cereal aphids parasitized by the parasitic wasps) and hyperparasitism ( $\left.N_{\text {hyperparasitoid }} /\left(N_{\text {parasitoid }}+N_{\text {hyperparasitoid }}\right)\right)$ were then calculated (Gagic et al. 2011; Lohaus, Vidal, \& Thies 2013).

Brewer and Elliott (2004) classified that all leaf-dwelling predators (e.g. lady beetle, lacewing, and hover fly) are specialists and all ground-dwelling predators (e.g. spiders and carabid beetles) are generalist. Therefore, we used sweep net method to collect specialist predators and pitfall trap method to collect generalist predators. Sweep nets were used to collect specialist predators $(H$. variegata and $H$. tredecimpunctata) on 10, 15 and 20 May each year. A standard sweep involved moving the open net through a semi-circle, and the sweep net was emptied every 10 strokes in the five-spot random sample. In each site, a total of 50 nets were conducted, and the population density of specialist predators was 
calculated as individuals per spot. All captured insects were killed and preserved in $80 \%$ ethanol. At the same time, pitfall traps were employed to capture ground-dwelling generalist predators in the spots selected for the five-spot random sample. Pitfall traps consisted of $450 \mathrm{ml}$ plastic cups dug down with the opening level to the ground and filled with $80 \mathrm{ml}$ of $33 \%$ ethylene glycol. Within each spot, the distances between the traps were kept below $1 \mathrm{~m}$. Traps were placed in the field from 5 to 15 May each year to collect generalist predators continuously and were changed every five days. The activity density of generalist predators were calculated as individuals per spot (Schmidt, Roschewitz, Thies, \& Tscharntke 2005). All adult generalist and specialist predators were identified to species (see Appendix A: Table A2). Predator-prey ratio ( $\left.N_{\text {predators }} / N_{\text {aphids }}\right)$ was then calculated separately for generalist and specialist predators, where $N_{\text {predators }}$ and $N_{\text {aphids }}$ represent the population densities of predators and cereal aphids, respectively.

\section{Statistical analyses}

The population densities of cereal aphids and their natural enemies were first examined in a preliminary test for signals of spatial autocorrelation using Moran's I statistics, with no spatial autocorrelation detected. Data from three sampling periods each year were treated as replicates and log-transformed to meet assumptions of normality and homogeneity of variance. Pearson's correlation coefficients were used to present the relationship between the inter-annual landscape change and the population densities of cereal aphids and natural enemies (SAS Institute Inc 2006; Werling \& Gratton 2010).

A generalized linear model (GLM) with the restricted maximum likelihood method was used to examine the effects of and the potential interaction between the inter-annual change in relative wheat crop cover $(\Delta \%)$ and the year of experiment on population density, species diversity, parasitism and predator-prey ratio. Nonlinear regression was also conducted to analyze the relationship between inter-annual landscape change and the species diversity of parasitoids, which follows a quadratic function (SAS Institute Inc 2006). Redundancy analysis (RDA) was used to determine the influence of inter-annual landscape change on different insect species (CANOCO 4.5), with the inter-annual landscape change as an environmental variable and population densities of cereal aphids and their natural enemies as dependent variables.

\section{Results}

Total cereal aphid density declined significantly from 2009 to 2011 (see Appendix A: Table A3), with the density in both 2009 and 2010 above the economic spray threshold (450 individuals/100 tillers; Larsson 2005; Li, Liu, \& Liu
1994). Eleven parasitoid species and six hyperparasitoid species were collected in our experiments. Aphidius avenae and $A$. gifuensis were two the dominant species of parasitic wasps, which accounted for $95 \%$ of all parasitoids. The three dominant hyperparasitoids (A. suspensus, P. aphidis and $A$. sp.) accounted for more than $80 \%$ of the total hyperparasitoids collected (see Appendix A: Table A3). Predators were species-rich, with 49 generalist and 35 specialist species collected. Only two dominant species in each group (generalist predators: P. astrigera and C. pallipes; Specialist predators: $H$. variegata and $H$. tredecimpunctata) were considered (see Appendix A: Table A3), accounting for about $40 \%$ of all predator individuals caught. These species have a wide distribution and high abundance in the crop fields and provide important bio-control services to suppress pests.

Densities of two aphid species declined when the proportion of wheat field area increased inter-annually, supporting the dilution and crowding effects except for S. graminum in 2010 (see Appendix A: Table A4; Table 1). Relationships between inter-annual landscape change and the population densities of parasitoids were significant, and the effect of inter-annual landscape change on parasitism was significant. Generalist predators and the generalist predator-prey ratio did not respond to the inter-annual landscape change, with the correlations varying greatly from year to year (see Appendix A: Table A4; Table 1). In contrast, densities of specialist predators declined consistently in response to the inter-annual wheat crop area expansion, and the specialist predator-prey ratio showed a significant negative response to the inter-annual landscape change of wheat crop area. The densities of hyperparasitoids were not consistently sensitive to inter-annual landscape change. Only the correlations between hyperparasitism by Alloxysta sp. on Aphidius avenae and inter-annual landscape change were found to be consistently strong (see Appendix A: Table A4). In addition, population densities, except for Alloxysta sp., were also sensitive to the year of experiment but the interaction of year and landscape change variable was not found (Table 1).

Relationship between species diversity of primary parasitoids and the inter-annual landscape change was not linear but followed a quadratic function $\left(F_{1,67}=3.46, P=0.04\right.$, Fig. 1A), suggesting a declining diversity regardless of the direction of the inter-annual landscape change. Species diversity of specialist predators was also sensitive to inter-annual landscape change $\left(F_{1,67}=8.82, P=0.01\right.$, Fig. $\left.1 \mathrm{~B}\right)$, with the non-significant response of generalist predators $\left(F_{1,67}=0.36\right.$, $P=0.37$, Fig. 1B). Parasitism decreased with the expansion of wheat crop areas $\left(F_{1,67}=15.32, P=0.01\right.$, Fig. $\left.1 C\right)$. The specialist predator-prey ratio declined with the expansion of wheat crop areas $\left(F_{1,67}=45.34, P=0.01\right.$, Fig. 1D), no changes of generalist predator-prey ratio $\left(F_{1,67}=0.75\right.$, $P=0.26$, Fig. 1D). Moreover, predator-prey ratio, diversity and species richness were not sensitive to the year of experiment (Table 1).

Natural enemies of cereal aphids responded differently to the inter-annual landscape change (Fig. 2), with the effects 
Table 1. Annual mean ( $\pm \mathrm{SE}$ ) of population density (the dominant ones in the respective functional group), parasitism, predator-to-prey ratio, Shannon diversity and species richness, as well as the significance level of inter-annual landscape change $\left(P_{\text {Site }}\right)$, year of experiment $\left(P_{\text {Year }}\right)$ and their interaction $\left(P_{\mathrm{S} \times \mathrm{Y}}\right)$ from the generalized linear model.

\begin{tabular}{|c|c|c|c|c|}
\hline & Annual mean $\pm \mathrm{SE}$ & $P_{\text {Site }}$ & $P_{\text {Year }}$ & $P_{\mathrm{S} \times \mathrm{Y}}$ \\
\hline Total cereal aphid density & $457.51 \pm 82.62^{\mathrm{a}}$ & 0.001 & 0.001 & 0.828 \\
\hline Macrosiphum avenae & $274.75 \pm 56.38^{\mathrm{a}}$ & 0.001 & 0.001 & 0.203 \\
\hline Schizaphis graminum & $142.13 \pm 33.65^{\mathrm{a}}$ & 0.074 & 0.001 & 0.249 \\
\hline Total parasitoid density & $75.63 \pm 13.91^{\mathrm{a}}$ & 0.001 & 0.001 & 0.124 \\
\hline Aphidius avenae & $55.89 \pm 10.34^{\mathrm{a}}$ & 0.001 & 0.001 & 0.374 \\
\hline Aphidius gifuensis & $19.58 \pm 7.59^{\mathrm{a}}$ & 0.023 & 0.002 & 0.282 \\
\hline Total hyperparasitoid density & $42.15 \pm 5.28^{\mathrm{a}}$ & 0.013 & 0.001 & 0.592 \\
\hline Asaphes suspensus & $13.50 \pm 2.49^{\mathrm{a}}$ & 0.774 & 0.001 & 0.291 \\
\hline Pachyneuron aphidis & $13.65 \pm 2.59^{\mathrm{a}}$ & 0.001 & 0.001 & 0.450 \\
\hline Alloxysta sp. & $11.19 \pm 1.42^{\mathrm{a}}$ & 0.208 & 0.238 & 0.342 \\
\hline Total generalist predator density & $37.09 \pm 11.56^{\mathrm{b}}$ & 0.139 & 0.001 & 0.837 \\
\hline Pardosa astrigera & $13.21 \pm 4.19^{\mathrm{b}}$ & 0.151 & 0.001 & 0.886 \\
\hline Chlaenius pallipes & $8.97 \pm 3.27^{b}$ & 0.417 & 0.001 & 0.946 \\
\hline Total specialist predator density & $28.03 \pm 8.80^{\mathrm{b}}$ & 0.001 & 0.001 & 0.093 \\
\hline Hippodamia variegata & $10.31 \pm 3.85^{\mathrm{b}}$ & 0.001 & 0.001 & 0.176 \\
\hline Hippodamia tredecimpunctata & $6.04 \pm 2.33^{\mathrm{b}}$ & 0.001 & 0.001 & 0.253 \\
\hline Parasitism & $17.67 \pm 2.57^{\mathrm{c}}$ & 0.083 & 0.001 & 0.041 \\
\hline Generalist predator-to-prey ratio & $8.09 \pm 1.90^{\mathrm{c}}$ & 0.986 & 0.224 & 0.962 \\
\hline Specialist predator-to-prey ratio & $6.07 \pm 1.29^{c}$ & 0.001 & 0.712 & 0.095 \\
\hline Parasitoid diversity & $1.84 \pm 0.12$ & 0.001 & 0.110 & 0.035 \\
\hline Generalist predator diversity & $2.82 \pm 0.29$ & 0.295 & 0.675 & 0.376 \\
\hline Specialist predator diversity & $2.05 \pm 0.20$ & 0.052 & 0.137 & 0.171 \\
\hline Parasitoid richness & $9.92 \pm 1.05$ & 0.012 & 0.657 & 0.026 \\
\hline Generalist predator richness & $42.16 \pm 3.32$ & 0.112 & 0.931 & 0.135 \\
\hline Specialist predator richness & $29.79 \pm 1.93$ & 0.028 & 0.101 & 0.907 \\
\hline
\end{tabular}

Significant effects $(P<0.05)$ were indicated in bold.

${ }^{a}$ Unit: individuals per 100 tillers for aphids, individuals emerged from the aphid mummies per 100 tillers for parasitoids and hyperparasitoids.

${ }^{\mathrm{b}}$ Unit: individuals per spot (5 traps per spot for generalist predators and 10 nets per spot for specialist predators).

${ }^{\mathrm{c}}$ Unit: percentage.

of inter-annual landscape change on specialist predators and parasitoids greater than on hyperparasitoids and generalist predators. Densities of cereal aphids were correlated best to one parasitic wasp (A. avenae) according to the RDA, and then, arranged from strong to weak, correlated to their specialist predators, hyperparasitoids, and generalist predators.

\section{Discussion}

As parasitoids and hyperparasitoids experienced strong dilution and crowding effects during the experiments, the inter-annual landscape change can indeed play an important role in the biological control. Parasitoids and specialist predators appeared to be more sensitive to the inter-annual landscape change than generalist predators. Specialist predators were also more affected by changing environments than their preys (Klapwijk, Lewis, \& Lewis 2012; Thies et al. 2008). However, as generalist predators can prey on a large number of insect species across a wide area (Cobbold \&
MacMahon 2012), their densities are fairly stable due to the spillover effect across the mosaic landscapes (Rand, Tylianakis, \& Tscharntke 2006) and are, as a result, not significantly affected by inter-annual change in the relative cover of wheat fields. Generalist predators can, therefore, provide a rather stable bio-control service. Furthermore, as they always remain in crop fields or surrounding habitats in winter (D'Alberto, Hoffmann, \& Thomson 2012; Wäckers et al. 2008) a new generation of generalist predators can be killed by agricultural activities during the sowing period in spring (Thies et al. 2008), buffering the variation in their population densities.

Different responses of these insects to inter-annual landscape change could be correlated with their dispersal ability and local population density (Schmidt et al. 2005). With strong mobility, cereal aphids, parasitoids and specialist predators can move into natural habitats for over-wintering after harvesting due to the absence of food resources and then move back into the wheat field in the following year from field margins, surrounding woodlands or grasslands (Thies 
(A)

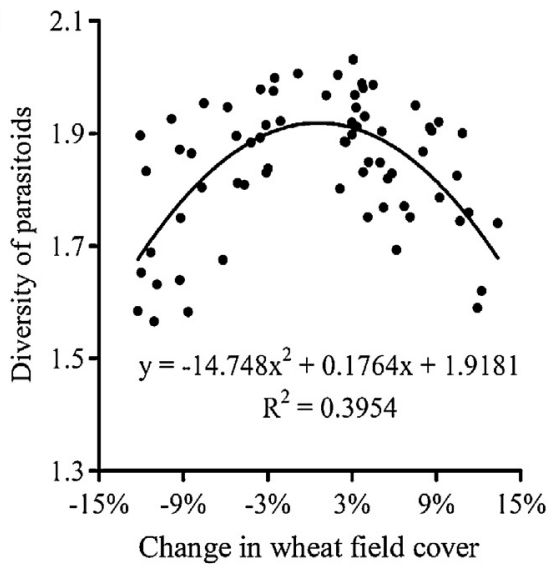

(B)

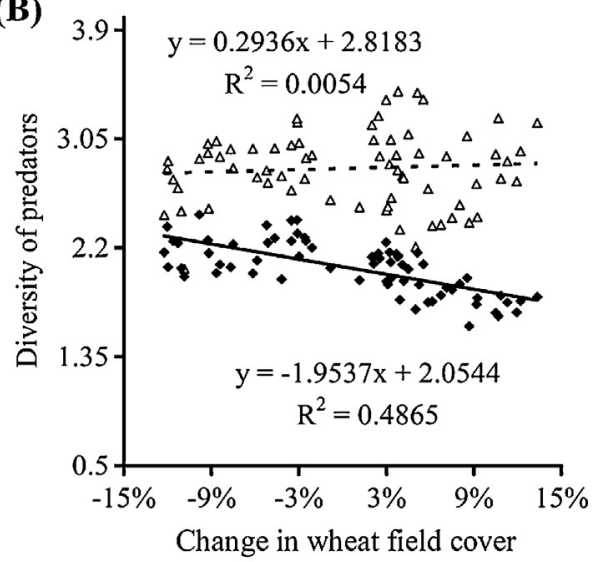

(D)

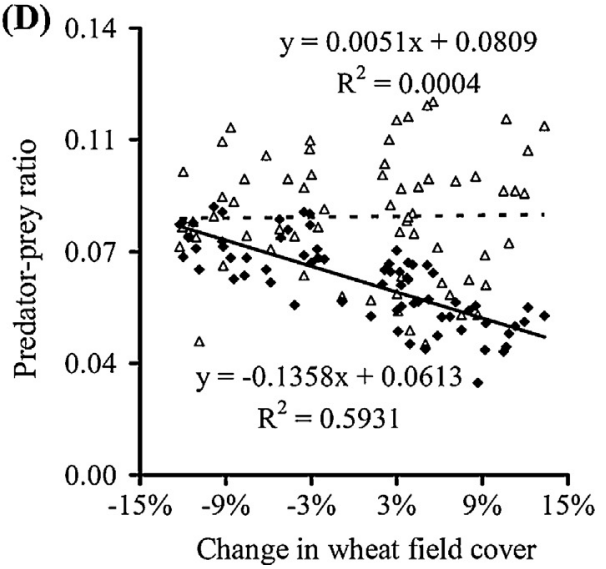

Fig. 1. The effect of inter-annual landscape change on the diversity (Shannon index) of parasitoids (A), the diversity of predators (B): $\Delta$ for generalists and $\checkmark$ for specialists), parasitism (C), and the predator-to-prey ratio (D). Note that $\Delta$ represents generalist predators and $\checkmark$ specialist predators in (B) and (D). Solid lines and dotted lines indicated significance and non-significance respectively.

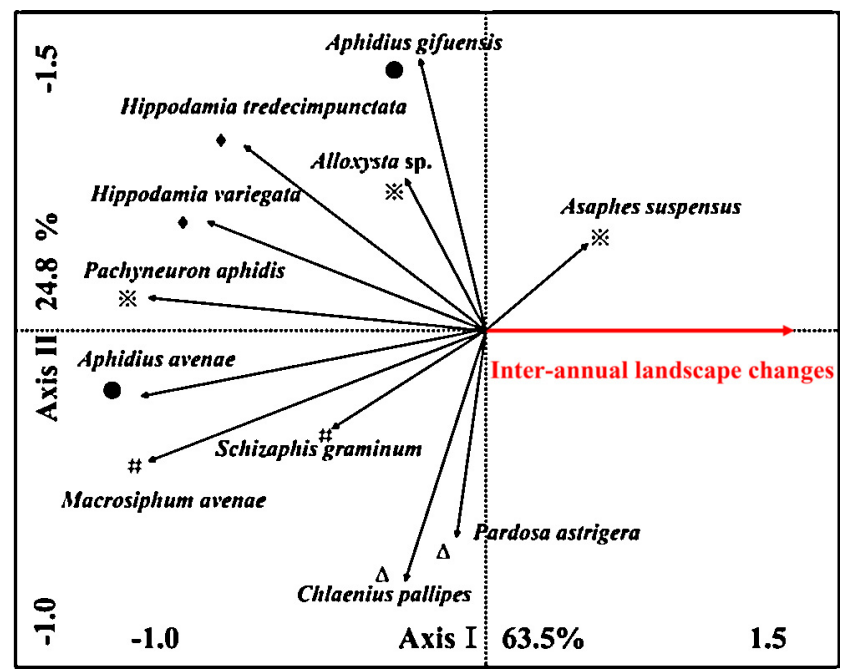

Fig. 2. Redundancy analysis (RDA) of the inter-annual landscape change of wheat crop area and insect densities (\# represents cereal aphids, $\Delta$ generalist predators, $\$$ specialist predators, $\bigcirc$ parasitoids, and $\square$ hyperparasitoid). et al. 2008). Their population densities are, therefore, more determined by these migrants, rather than local populations (Brewer \& Elliott 2004). The uncertainty of migration will undoubtedly weaken the dilution and crowding effects. In this regard, their responses to inter-annual landscape change can only be captured at broader spatial scales (Géneau, Wäckers, Luka, Daniel, \& Balmer 2012; Holland, Birkett, \& Southway 2009).

The effect of inter-annual landscape change can be further complicated by host alteration as some parasitoids and hyperparasitoids may parasitize other species from surrounding habitats, making them insensitive to the changes of host densities in the focal wheat fields. In contrast, short life span and high reproductive rate may be a contributing factor to the rapid response to inter-annual landscape change (Leslie, Werf, Bianchi, \& Honĕk 2009). These sensitive species that experience the crowding and dilution effects could have adapted well to local agricultural landscape change (Zaller et al. 2009), whilst insensitive species tend not to benefit from local habitat manipulation but might be responding to broader-scale regional disturbances.

Evidently, the hypothesis that species in higher trophic levels are more sensitive to environmental changes was not well 
supported. Although cereal aphids were sensitive to interannual landscape change, at high trophic levels only specialist predators were consistently sensitive to the inter-annual landscape change. Species from different trophic levels showed no general trend of increase or decrease in their sensitivity to the inter-annual wheat crop area changes.

To fully understand the relationship between inter-annual landscape change and cereal aphid-natural enemy interactions, it is necessary to assess dispersal mechanisms of natural enemies, where and on which hosts overwintering occurs for these natural enemies and within which hosts (Brewer \& Elliott 2004; Tscharntke et al. 2012). It is also important to consider population dynamics regulated by spatiotemporally demographic mechanisms (e.g. Hui 2011; Hui, Boonzaaier, \& Boyero 2012; Horak, Hui, Roura-Pascual, \& Romportl 2013), other than the dilution and crowding effects. Studies are needed for quantifying the potential effect of host density on parasitism and hyperparasitism and the interference between parasitoids competing for hosts (Haenke et al. 2009; Soufbaf, Fathipour, Hui, \& Karimzadeh 2012; Thies et al. 2011). In conclusion, differences in cereal aphid-natural enemy interactions suggest that inter-annual agricultural landscape change is an important but complex factor for consideration when optimizing the efficacy of biological pest control (Tscharntke et al. 2012; Zhao et al. 2012).

\section{Acknowledgements}

We are grateful to Klaus Hövemeyer and three anonymous referees for constructive comments, to Ying Wang and Ying-shu Zhao for field assistance and to Beverley Laniewski for English editing. Financial support came from the State Key Program of National Natural Science of China (Nos. 31030012, 31260429). CH is supported by the Incentive Research Program of the National Research Foundation.

\section{Appendix A. Supplementary data}

Supplementary data associated with this article can be found, in the online version, at http://dx.doi.org/ 10.1016/j.baae.2013.06.002.

\section{References}

Bianchi, F. J. J. A., Booij, C. J. H., \& Tscharntke, T. (2006). Sustainable pest regulation in agricultural landscapes: A review on landscape composition, biodiversity and natural pest control. Proceedings of the Royal Society of London Series B, 173, $1715-1727$.

Brewer, M. J., \& Elliott, N. C. (2004). Biological control of cereal aphids in North American and mediating effects of host plant and habitat manipulation. Annual Review of Entomology, 49, 219-242.
Cobbold, S. M., \& MacMahon, J. A. (2012). Guild mobility affects spider diversity: Links between foraging behavior and sensitivity to adjacent vegetation structure. Basic and Applied Ecology, 13, 597-605.

D’Alberto, C. F., Hoffmann, A. A., \& Thomson, L. J. (2012). Limited benefits of non-crop vegetation on spiders in Australian vineyards: Regional or crop differences? Biocontrol, 57, $541-552$.

Environmental Systems Research Institute. (2008). ArcGIS, version 9.3. Available at. http://www.esri.com/software/arcgis/ index.html

Gagic, V., Tscharntke, T., Dormann, C. F., Gruber, B., Wilstermann, A., \& Thies, C. (2011). Food web structure and biocontrol in a four-trophic level system across a landscape complexity gradient. Proceedings of the Royal Society of London Series B, 278, 2946-2953.

Géneau, C. E., Wäckers, F. L., Luka, H., Daniel, C., \& Balmer, O. (2012). Selective flowers to enhance biological control of cabbage pests by parasitoids. Basic and Applied Ecology, 13, 85-93.

Grez, A., Zaviezo, T., Tischendorf, L., \& Fahrig, L. (2004). A transient, positive effect of habitat fragmentation on insect population densities. Oecologia, 141, 444-451.

Haenke, S., Scheid, B., Scharfer, M., Tscharntke, T., \& Thies, C. (2009). Increasing syrphid fly diversity and density in sown flower strips within simple vs. complex landscapes. Journal of Applied Ecology, 46, 1106-1114.

Holland, J. M., Birkett, T., \& Southway, S. (2009). Contrasting the farm-scale spatio-temporal dynamics of boundary and field overwintering predatory beetles in arable crops. Biocontrol, 54, 19-33.

Horak, J., Hui, C., Roura-Pascual, N., \& Romportl, D. (2013). Changing roles of propagule, climate, and land use during extralimital colonization of a rose chafer beetle. Naturwissenschaften, 100, 327-336.

Hui, C. (2011). Forecasting population trend from the scaling pattern of occupancy. Ecological Modelling, 222, 442-446.

Hui, C., Boonzaaier, C., \& Boyero, L. (2012). Estimating changes in species abundance from occupancy and aggregation. Basic and Applied Ecology, 13, 169-177.

Klapwijk, M. J., Lewis, O. T., \& Lewis, O. T. (2012). Host-parasitoid dynamics in a fragmented landscape: Holly trees, holly leaf miners and their parasitoids. Basic and Applied Ecology, 13, 94-105.

Larsson, H. (2005). Economic damage by Limothrips denticornis in rye, triticale and winter barley. Journal of Applied Entomology, 129, 386-392.

Leslie, T. W., Werf, V. D., Bianchi, F. J. J. A., \& Honĕk, A. (2009). Population dynamics of cereal aphids: Influence of a shared predator and whether. Agricultural and Forest Entomology, 11, 73-82.

Li, S. G., Liu, A. Z., \& Liu, S. M. (1994). Study on the relationships among wheat aphids, natural enemy and yield loss of wheat and the action threshold of aphids. Acta Phytophylacica Sinica, 21, 15-18 (in Chinese)

Lohaus, K., Vidal, S., \& Thies, C. (2013). Farming practices change food web structures in cereal aphids-parasitoid-hyperparasitoid communities. Oecologia, 171, 249-259.

Otway, S. J., Hector, A., \& Lawton, J. H. (2005). Resource dilution effects on specialist insect herbivores in a grassland biodiversity experiment. Journal of Animal Ecology, 74, 234-240. 
Rand, T. A., Tylianakis, J. M., \& Tscharntke, T. (2006). Spillover edge effects: The dispersal of agriculturally subsidized insect natural enemies into adjacent natural habitats. Ecology Letters, 9, 603-614.

SAS Institute. (2006). SAS User's Guide: Version 9.1.2. Cary, NC, USA: SAS Institute.

Schmidt, M. H., Roschewitz, I., Thies, C., \& Tscharntke, T. (2005). Differential effects of landscape and management on diversity and density of ground-dwelling farmland spiders. Journal of Applied Ecology, 42, 281-287.

Schmidt, M. H., Thies, C., Nentwig, W., \& Tscharntke, T. (2008). Contrasting response of arable spiders to the landscape matrix at different spatial scales. Journal of Biogeography, 35, 157-166.

Soufbaf, M., Fathipour, Y., Hui, C., \& Karimzadeh, J. (2012). Effects of plant availability and habitat size on the coexistence of two competing parasitoids in a tri-trophic food web of canola, diamondback moth and parasitic wasps. Ecological Modelling, 244, 49-56.

Thies, C., Haenke, S., Scherber, C., Bengtsson, L., Bommarco, R., Clement, L. W., et al. (2011). The relationship between agricultural intensification and biological control: Experimental tests across Europe. Ecological Applications, 21, 2187-2196.
Thies, C., Steffan-Dewenter, I., \& Tscharntke, T. (2008). Interannual landscape changes influence plant-herbivore-parasitoid interactions. Agriculture, Ecosystems and Environment, 125, 266-268.

Tscharntke, T., Tylianakis, J. M., Rand, T. A., Didham, R. K., Fahrig, L., Batary, P., et al. (2012). Landscape moderation of biodiversity patterns and processes-Eight hypotheses. Biological Review, 87, 661-685.

Wäckers, F., van Rijn, P., \& Heimpel, G. (2008). Honeydew as a food source for natural enemies: Making the best of a bad meal? Biological Control, 45, 176-184.

Werling, B. P., \& Gratton, C. (2010). Local and broad scale landscape structure differentially impact predation of two potato pests. Ecological Applications, 20, 1114-1125.

Zaller, J. G., Moser, D., Drapela, T., \& Frank, T. (2009). Ground-dwelling predators can affect within-field pest insect emergence in winter oilseed rape fields. Biocontrol, 54, 247-253.

Zhao, Z. H., He, D. H., \& Hui, C. (2012). From the inverse density-area relationship to the minimum patch size of a host-parasitoid system. Ecological Research, 27, 303-308.

Available online at www.sciencedirect.com 